\title{
Adjustments of the Elderly to Declining Health: Residential Moves and Social Support
}

\author{
Eric G. Moore \\ Donald L. McGuinness \\ Queen's University \\ Kingston, Ontario, Canada
}

\begin{abstract}
As the Canadian population ages, adjustments to deteriorating health play an important part in structuring demands for health care and social services. Litwak and Longino have argued that residential moves in response to a need for greater social support from family constitute an important element in elderly mobility and migration. We use data from the Health and Activity Limitation Survey (HALS) and the Survey on Aging and Independence (SAI) to show that support moves constitute about one-third of all moves among the older elderly, but that support moves also have consequences in terms of reducing access to friends and generating lower usage of formal services. There is also some evidence that regions with slower economic growth have higher proportions of in-movers who are support movers, which is consistent with a general view that the dynamics of aging result in greater service demands in more disadvantaged areas.
\end{abstract}




\section{Résumé}

Vue que la population Canadiènne est vieillisante, les ajustments à une santé en declin jouent un rôle important dans la structure du besoin pour les services de santé et les services sociales. Litwak et Longino ont affirmé que la mobilité residentielle comme réponse au besoins $\mathrm{d} N$ assistancefamilliale constitue un élément important dans la mobilité et la migration des personnes agées. Utilisons les donnés munis par 1Enquête sur la santé et les limitations

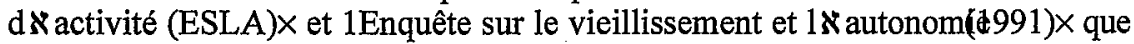
les changements $\mathrm{d} \boldsymbol{\kappa}$ addresse en quête $\mathrm{d} \boldsymbol{N}$ appui constituent vers un tiers de toultes changements $d \aleph$ addressespour les vieilles gens, mais que ces changements $\mathrm{d} \aleph$ addresseont aussi des conséquences comme une réduction $\mathrm{d} \aleph \mathrm{accessau}$ amis, et une réduction dans $1 \mathrm{k}$ utilisationdes services formels. Il y a aussi quelques indications que les régions avec une croissance économique plus lente ont une proportion plus large de migrants en quête $d \aleph$ appui.Ces résultats conforment à IKhypothèsegénérale que la vieillissement produit un besoin pour les services sociales plus large dans des régions désavantagées.

Key Words: aging, elderly mobility, migration, elder support systems

\section{Introduction}

Residential mobility and migration among the elderly population raise important questions both for theoretical analysis and for public policy, particularly as both the relative and absolute size of the elderly population increases in every developed country (Northcott, 1988). On the theoretical level it is important to develop an appropriate framework which recognizes that the mix of motivations and movement-triggering events among the elderly have a different character from that for the younger population in the labour force years. From a policy perspective, the fiscal pressures exerted on the demand for health care and social services by a growing elderly population require an attention to mobility behaviour which changes both the nature and the geographical locus of these demands.

Canada has much in common with other developed nations in terms of the growth and impact of an aging population (OECD, 1996). The proportion of the Canadian population which is over 65 has been growing steadily for most of the post-war period, with the fastest rates being associated with the oldest agegroups (Moore, Rosenberg and McGuinness, 1997). Canada is a mobile society and, while the elderly are clearly less prone to change their residence in any given time period than those who are younger, they nonetheless exhibit a significant level of both local mobility and longer distance migration. Elsewhere, we have demonstrated that the nature of population aging is strongly differentiated in geographical terms by the relative importance of elderly and nonelderly migration and aging in place. The variation in these factors is firmly 
linked to variations in local economic conditions (Moore, Rosenberg and McGuinness, 1997; Moore and McGuinness, 1997), with the higher concentrations of the elderly and the dominance of aging by migration being associated with communities that are economically disadvantaged. The differential effects of migration on the quantitative aspects of local population aging, however, says little about the composition of those changes. In particular, are those economically disadvantaged communities which experience high relative rates of population aging also characterized by an accumulation of elderly in poorer health and in greater need of social services? This question requires a better understanding of the nature and consequences of mobility and migration among the elderly (Speare and Mayer, 1988).

In this paper, we focus on the context of individual moves by elderly Canadians and also on changes in access to formal and informal support as a consequence of these moves. Particular attention is given to the second element of the wellknown Litwak and Longino (1987) framework which stresses the importance of moves to increase the level of social support, especially from family, stimulated by actual or anticipated declines in health and the ability to function independently. In the next section, we provide a brief review of the life-course perspective on elderly migration. A model of migration is then estimated using data from the 1986 Health and Activity Limitation Survey (HALS). A second data source, the 1991 Survey of Aging and Independence (SAI), is used to identify the primary motives for moving for different subgroups of the population, focusing specifically on variations in the importance of support moves. The same source is used to indicate some of the social consequences of support moves for the individuals involved. Finally, comments are offered on the implications of these findings both for public policy and for future research.

\section{The Life Course Perspective on Elderly Migration}

Interest in elderly mobility has increased dramatically since the 1970s, largely in response to increases in the impacts of these movements on issues of public policy in developed nations (Wiseman and Roseman, 1979). A number of typologies of elderly mobility have been proposed in an attempt to examine and understand the driving factors behind elderly mobility and the consequences for both the individuals involved and the larger society.

The most influential framework was formulated by Litwak and Longino (1987) who set out an explicitly developmental perspective on elderly migration which focused on three different types of moves associated with the life-course of the elderly. In the first stage, usually associated with retirement from the labour force, moves were most likely to be undertaken to enhance the value derived from local amenity (moves to warmer climates, more attractive surroundings and access to recreation). A second set of moves were seen to arise as individuals age and experience declines in health and increases in disability which affect the ability to function independently; these moves tend to be motivated by the desire for increased social support, particularly from family. Moves to be closer to children are significantly more likely among those with declining health 
(Speare, Avery and Lawton, 1991; Silverstein, 1995). The final stage in their typology is associated with significant increases in the severity of chronic disability and the need for a level of social and health care support which requires a move to an institutional setting where such care can be provided. The Litwak and Longino framework highlights the role played by significant events in the elderly life-course. However, many of the factors appropriate to discussion of mobility in the larger population are also relevant and the central issue for the analysis of elderly mobility concerns the way in which the mix of motives shifts for the elderly population. As DeJong et al. (1995) point out, the Litwak and Longino framework can be embedded in the more general framework of migration theory which emphasizes the relationships between individual values and expectations and migration responses (DeJong and Fawcett, 1981); elderly individuals also move for reasons relating to financial pressures, desire for more appropriate housing, relations to employment and to family which are unrelated to the need for support. It is important to understand how the relative importance of these motivations change with age and the consequences of such shifts both for the individual and for the society at large (Meyer and Speare, 1985).

Mobility behaviour is often conceptualized as an adjustment mechanism which permits change in everyday lives in response to stress in the previous location. These stresses are brought about either by accumulations of lesser stresses over a long period or by sudden changes precipitated by particular life events such as death of a spouse or job loss. This view also raises questions about outcomes which have received too little attention in the mobility literature. At the individual level, do the adjustments achieve the changes expected in everyday life? At the aggregate level, what are the redistributional effects across geographical jurisdictions which are generated by selective mobility? There is another side to the individual level question which also has serious implications; do those who are exposed to similar stresses but who are unable to move experience significant negative consequences (Michelson, 1977)? This is particularly pertinent in the case of 'support movers', since those who do not have family members to provide needed support may be unable to make such a 'support move' and are likely to generate high levels of demand for formal health care and other services.

The third stage of the Litwak and Longino framework, the transfer to an institution, is poorly understood, either in its relation to the characteristics of elderly individuals or in its geographical manifestations. The latter is particularly intriguing as even the fairly limited analysis possible in Canada shows significant differences in the geography of institutionalization. At the provincial level, Manitoba, which has been a pioneer in the home care field, has significantly lower rates of institutionalization than other provinces and there are also significant variations at the local level (Moore, Rosenberg and McGuinness, 1997). Transfers to institutions are not just a function of deteriorated health status. In a society with increasing proportions of elderly, especially women, who live alone and who often have no family to whom they can turn for daily help, institutionalization is too often an unavoidable solution. 


\section{Data Issues}

Ideally, an analysis of mobility behaviour and its consequences for individuals should have access to a longitudinal file such that the characteristics of individuals together with changes in their life prior to a move can be considered. The Longitudinal Study on Aging (LSOA) is particularly important in this regard and has led to significant insights into the underpinnings of elderly mobility in the U.S. (Speare, Lawton and Avery, 1991; DeJong et al., 1995; Silverstein, 1995). In Canada, we await the release of the linked files of the first two waves of the National Population Health Survey (NPHS) which has the potential to generate similar insights with a stronger health perspective. However, we do have a number of files which contain mobility, health and social support information for the elderly which, together with the Public Use Microdata Files (PUMF) from the five-year censuses, can provide useful insight into the structure and consequences of mobility in Canada.

The Health and Activity Limitation Surveys were post-censal surveys undertaken in 1986 and 1991. HALS contained 175000 respondents in 1986 and 105000 in 1991. HALS is linked to the 1991 Census through questions on the Census long form (the 20 percent sample) about activity limitations and disabilities. The responses to the census questions provided the sampling frame for the HALS survey which emphasized the measurement of activity limitation and the broad range of socio-economic and demographic conditions which influence its prevalence and its impacts. It allows measures of health status based on functioning with respect to both ADLs and IADLs and provides important insights into the use of both formal and informal supports. HALS is also important in that it has a separate survey component which focuses on health-related institutions and is the only source available which allows some estimates to be made of the health status of the total elderly population including populations both in the institutional and non-institutional populations.

An additional source which is of particular value in examining certain aspects of social support and independent living is the Survey on Ageing and Independence (SAI). SAI was conducted in September 1991 to measure factors which contribute to the quality of life and independent living of the elderly in Canada. The survey of 25000 individuals over 45 was designed to examine a broad range of characteristics of the elderly in Canada and those currently preparing for the older years. Specifically, the objectives of the survey were to provide national level estimates concerning the health, social and economic situation for the population over the age of 65 . The survey was also designed to provide national level estimates of the population between the ages of 45 and 64 concerning their planning choices and preparations with regard to aging. The value of SAI for this study is that it reports reasons for moving as well as quantitative data on the number, characteristics and location of family members. 
It is unfortunate that the definition of 'move' in SAI does not permit differentiation between local and long distance moves which means that one cannot test propositions about certain geographical aspects of such moves. HALS allows a limited classification of local moves versus long-distance moves but does not contain any additional information on the move itself. The task is then one of piecing together analyses from different surveys in terms of their consistency with a broader theoretical framework rather than making them consistent with each other.

\section{The Movement Behaviour of Elderly Canadians}

Initially, we examine the relations between socio-demographic attributes of individuals and their propensity to move, using the 1991 PUMF. Mobility is defined in terms of changing residence between the 1986 and 1991 Censuses of Population. The overall likelihood of moving declines slightly with increasing age (Table 1), although moves into institutions are excluded from these data. As with younger populations, the most dramatic differences are between owners and renters. The greater attachment to place experienced by owners and the much higher costs of relocation produces markedly lower movement rates for owners at all ages; furthermore, with over 70 percent of elderly owners being mortgage free, staying in the home is often the lowest cost alternative (Moore and Rosenberg, 1993). For older owners, only 15 to 20 percent of both males and females have moved during the period 1986-1991. These movers are split almost equally between local movers and migrants (both internal and international). A little over 1 percent of the elderly population immigrated to Canada during that period. Age effects are small but consistent with the proportion who are stayers increasing steadily from 55-59 to 80-84 and then a small drop for the oldest age group when the likelihood of moving to live with other members of the family increases dramatically. It is also at the oldest age that the propensity to move to an institution is greatest, but the migration data from the census only records those moves made by individuals in the previous five years who currently live in households.

The pattern is somewhat different for renters (Table 1). The proportion who are recent movers is much higher (30 to 50 percent in the last five years) with considerably stronger age effects than is the case for owners. For example, while 51.4 percent of 55-59 year old females have moved in the last five years, only 26.4 percent of those 85 and over have moved within the non-institutional population. Clearly a significant number of individuals move from the community to institutional environments but there is no satisfactory way of estimating these flows at present. Among those adults in the community who have moved in the last five years, renters are twice as likely to have been local movers than migrants. Rental markets are much more flexible than owned markets and housing adjustments are easier and cheaper to make. As for the population as a whole, these types of moves from one rental unit to another are 
Adjustments of the Elderly to Declining Health: Residential Moves and Social Support

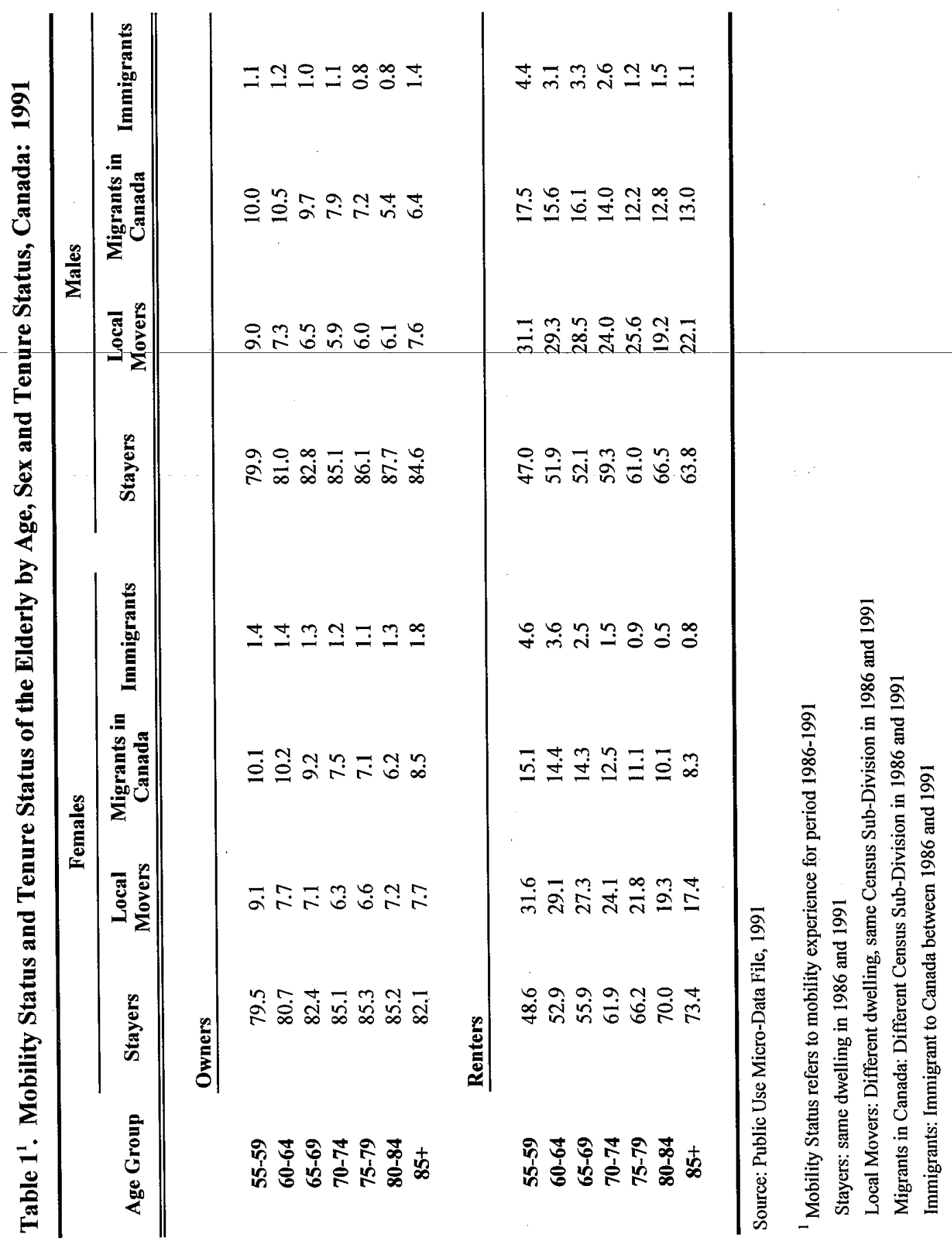


much more likely to be made within the same local area than over long distances.

Other relationships between socio-demographic variables and mobility are played out through differences in housing. Elderly individuals still living with their spouse or partner are the most likely to be living in stable, owner-occupied settings and they experience the lowest likelihood of moving (Table 2). In contrast, for those whose spouse is not present (i.e., are single, divorced or widowed) while the demographic status is likely to be quite stable, the individual is more likely to be a renter and this strongly influences the likelihood of being a mover; thus when single people move they are also more likely to be a local mover than a migrant.

Widows and those who are divorced or separated are more likely to be movers, since both groups are more likely to be lower income and to be renters, while those who have experienced recent transitions from married status are likely to have responded to these new circumstances by moving. The association with higher likelihood of moving is even stronger for those who are divorced or separated than for widows. Given the higher divorce rates at younger ages and the modest remarriage rates (Ram, 1990), the size of the divorced elderly population is likely to continue to grow over the next twenty years and will contribute to greater mobility among the elderly. At the same time, however, the increased longevity of males contributes to larger proportions of couples remaining intact during their later years and this will offset the divorce effects as intact couples are the most residentially stable group.

We must not fall into the trap of assuming that higher levels of residential mobility are necessarily socially undesirable. A modest level of mobility is necessary to permit individuals to adjust to changing personal circumstances. Stress is produced by two types of situation. First, stress results from moves which are imposed on individuals by circumstances beyond their control (e.g., by eviction and by other events such as sickness or loss of spouse). Second, stress may also be generated for those who wish to move but who are unable to do so for lack of opportunity or because the financial resources are not available to make a move. Both types of stress arising from forced moves and blocked moves are more likely to occur among those with limited incomes (Moore and Clark, 1987). In particular, there is a propensity for older individuals to become trapped in owner-occupied dwellings in relatively inaccessible locations which they can neither afford to sell nor to maintain properly. This situation has the potential to become more serious as the burgeoning suburban population in metropolitan areas ages (Golant, 1992). Particularly as this population loses its ability to get around independently, the lack of public transportation services makes access to other health and social services more difficult; if the population is unable to relocate to more advantageous locations, then the costs of delivering services on a per capita basis will increase.

The role played by health status in mobility behaviour is somewhat difficult to assess with the type of data available. In both surveys and censuses, characteristics of movers, including health status, tend to be measured after the 
Table 2.

Distribution of Mobility Status of the Elderly by Age, Sex and Marital Status, Canada: 1991

\begin{tabular}{|c|c|c|c|c|c|c|c|c|}
\hline \multirow[b]{2}{*}{ Age Group } & \multicolumn{4}{|c|}{ Fermales } & \multicolumn{4}{|c|}{ Males } \\
\hline & Stayers & $\begin{array}{c}\text { Local } \\
\text { Movers }\end{array}$ & $\begin{array}{l}\text { Migrants } \\
\text { in Canada }\end{array}$ & Immigrants & Stayers & $\begin{array}{c}\text { Local } \\
\text { Movers }\end{array}$ & $\begin{array}{l}\text { Migrants } \\
\text { in Canada }\end{array}$ & Immigrants \\
\hline . & Married & & & & & & & \\
\hline $55-59$ & $76.8^{1}$ & 10.5 & 10.8 & 1.9 & 76.0 & 11.4 & 10.8 & 1.8 \\
\hline $60-64$ & 77.8 & 9.5 & 11.0 & 1.7 & 77.3 & 9.8 & 11.2 & 1.7 \\
\hline $65-69$ & 79.4 & 9.4 & 9.8 & 1.4 & 78.2 & 9.4 & 10.8 & 1.5 \\
\hline $70-74$ & 81.8 & 8.7 & 8.8 & 0.8 & 80.6 & 8.7 & 9.1 & 1.6 \\
\hline $75-79$ & 81.6 & 9.4 & 8.5 & 0.5 & 81.4 & 9.8 & 7.9 & 0.9 \\
\hline $80-84$ & 81.6 & 9.3 & 8.2 & 0.9 & 83.4 & 8.7 & 7.0 & 1.0 \\
\hline \multirow{2}{*}{$85+$} & 81.5 & 11.2 & 6.6 & 0.7 & 80.4 & 11.3 & 7.3 & 1.0 \\
\hline & Single & & & & & & & \\
\hline 55-59 & 69.5 & 19.4 & 9.4 & 1.7 & 71.5 & 18.5 & 9.4 & 0.6 \\
\hline $60-64$ & 71.4 & 17.5 & 8.8 & 2.3 & 74.9 & 15.7 & 9.0 & 0.4 \\
\hline $65-69$ & 73.4 & 15.5 & 10.1 & 1.0 & 73.8 & 16.1 & 9.8 & 0.3 \\
\hline $70-74$ & 79.5 & 13.4 & 6.8 & 0.4 & 80.0 & 12.5 & 7.1 & 0.4 \\
\hline $75-79$ & 82.1 & 12.1 & 5.5 & 0.3 & 79.5 & 13.0 & 7.2 & 0.3 \\
\hline $80-84$ & 84.0 & 10.0 & 5.7 & 0.2 & 85.6 & 8.7 & 5.1 & 0.5 \\
\hline \multirow[t]{2}{*}{$85+$} & 78.5 & 15.0 & 5.2 & 1.4 & 72.6 & 12.8 & 12.8 & 1.7 \\
\hline & Widowed & & & & & & & \\
\hline $55-59$ & 66.6 & 18.6 & 11.1 & 3.7 & 72.0 & 15.1 & 8.9 & 4.0 \\
\hline $60-64$ & 68.9 & 17.1 & 11.1 & 2.9 & 69.7 & 15.9 & 12.2 & 2.1 \\
\hline $65-69$ & 70.3 & 15.9 & 11.3 & 2.4 & 73.5 & 14.2 & 9.7 & 2.6 \\
\hline $70-74$ & 73.9 & 14.8 & 9.2 & 2.1 & 75.9 & 13.2 & 9.6 & 1.3 \\
\hline $75-79$ & 75.5 & 14.2 & 8.9 & 1.4 & 76.5 & 13.3 & 9.7 & 0.6 \\
\hline $80-84$ & 77.5 & 13.7 & 7.7 & 1.0 & 75.2 & 13.0 & 10.6 & 1.2 \\
\hline \multirow[t]{2}{*}{$85+$} & 78.2 & 11.7 & 8.9 & 1.2 & 76.2 & 13.7 & 8.4 & 1.7 \\
\hline & \multicolumn{8}{|c|}{ Divorced or Separated } \\
\hline $55-59$ & 53.7 & 30.3 & 14.6 & 1.3 & 53.1 & 26.0 & 19.9 & 1.1 \\
\hline $60-64$ & 57.8 & 26.5 & 14.3 & 1.4 & 57.5 & 25.1 & 16.5 & 0.9 \\
\hline $65-69$ & 59.9 & 24.4 & 14.2 & 1.6 & 59.3 & 24.0 & 15.9 & 0.8 \\
\hline $70-74$ & 65.7 & 19.2 & 13.5 & 1.6 & 66.4 & 21.0 & 12.4 & 0.2 \\
\hline $75-79$ & 70.4 & 16.9 & 11.9 & 0.8 & 61.4 & 20.1 & 16.9 & 1.6 \\
\hline $80-84$ & 64.0 & 17.3 & 17.3 & 1.3 & 76.7 & 17.1 & 4.7 & 1.6 \\
\hline $85+$ & 70.9 & 12.7 & 12.7 & 3.6 & 66.1 & 12.9 & 21.0 & 0.0 \\
\hline
\end{tabular}

Source: Public Use Micro-Data File, 1991

'Proportion of married females age 55-59 who were stayers (lived in same dwelling in 1986 and 1991). 
fact. Furthermore, analysis by DeJong et al. (1995) using LSOA has shown that recent change in health status rather than health status per se is a more effective predictor of moving. Nevertheless, Table 3 provides some dimensions of the role of activity limitation in the mobility process. Among the activity limited, the general effects of age and marital status are similar to those in the population as a whole, including a general decline with increasing age for women and, for men, an increase as retirement is reached followed by a decline. Married individuals are much less likely to move than non-married individuals, although this is strongly related to the fact that married individuals are more likely to be owners. When the relative odds of having moved are calculated by activity

Table 3.

Activity Limitation and Mobility Status by Age, Sex and Marital Status, Canada: 1991

\begin{tabular}{|c|c|c|c|c|}
\hline \multirow{3}{*}{$\begin{array}{l}\text { Age } \\
\text { Group }\end{array}$} & \multicolumn{4}{|c|}{ Percent Who Moved in the Last 5 Years } \\
\hline & \multicolumn{2}{|c|}{ Married } & \multicolumn{2}{|c|}{ Not Married } \\
\hline & Male & Female & Male & Female \\
\hline & \multicolumn{4}{|c|}{ Not Activity Limited } \\
\hline $55-64$ & $19.1 \%$ & $17.5 \%$ & $28.6 \%$ & $34.2 \%$ \\
\hline $65-74$ & $16.6 \%$ & $17.7 \%$ & $30.1 \%$ & $21.8 \%$ \\
\hline \multirow[t]{2}{*}{$75+$} & $13.2 \%$ & $17.6 \%$ & $16.8 \%$ & $20.9 \%$ \\
\hline & \multicolumn{4}{|c|}{ Activity Limited } \\
\hline $55-64$ & $17.7 \%$ & $24.7 \%$ & $30.9 \%$ & $36.1 \%$ \\
\hline $65-74$ & $18.8 \%$ & $21.5 \%$ & $34.9 \%$ & $28.9 \%$ \\
\hline $75+$ & $15.6 \%$ & $15.0 \%$ & $23.2 \%$ & $18.8 \%$ \\
\hline
\end{tabular}

Relative Risk of Moving

\begin{tabular}{ccccc}
\hline \hline & \multicolumn{5}{l}{ Activity Limited/Not Activity Limited } \\
\cline { 2 - 5 } $\mathbf{5 5 - 6 4}$ & 0.92 & 1.41 & 1.08 & 1.06 \\
$\mathbf{6 5 - 7 4}$ & 1.13 & 1.22 & 1.16 & 1.32 \\
$\mathbf{7 5 +}$ & 1.18 & 0.85 & 1.37 & 0.90 \\
\hline
\end{tabular}

Source: Survey of Aging and Independence (1991) 
limitation, it is evident that, in general, those who are activity limited are more likely to have moved and this tendency is slightly stronger for those who are not married. The lower odds for women over 75 is of interest and it may well represent the inability of individuals in this group to find appropriate opportunities to move.

\section{The Role of Social Support}

In later years, changes in health status and the ability to continue to live independently create a different set of pressures and induce new forms of movement. Adjustments need to be made both in housing, if it becomes difficult to cope with the maintenance of too much space (especially exterior landscaping) or with climbing stairs, and in access to appropriate levels of social support. If it becomes difficult to look after an aging spouse or if one spouse dies or is institutionalized, then a move may occur to allow for greater access to long-time friends and family who may be able to give the necessary support (Litwak and Longino, 1987). It is important to remember that there is no sudden transformation of the structure of mobility with age; rather there is a steady shift in the distribution of the motivations for moving .

Reasons for moving reported in SAI can be classified into more general categories reflecting underlying motivations for moving (Table 4). Since individuals are allowed to indicate more than one reason and do not identify the primary reason, the initial analysis is of the distribution of reasons, with the number of responses being greater than the number of movers. As we might expect from the earlier discussion of changing reasons for moving with increasing age, the mix of motivations does change (Table 5). Retirement and employment related reasons show peaks respectively in the 65-69 and pre-65 age groups. Financial pressures decline somewhat as reasons for moving after the age of 70 and amenity related responses increase after retirement, the highest rates being for individuals aged 70-74. The relative importance of housing and marital disruptions remain fairly constant over the age range.

The most significant finding from the point of view of this paper is the steady and consistent increase in the role of support moves with increasing age (Table 5). Among those over 75, 28 percent of all reasons cited are 'support reasons', while more than 35 percent of movers list 'support reasons' as contributing to the move (movers may cite more than one reason for moving). The data in Table 5 are consistent with DeJong's findings (DeJong et al., 1995) that only about a third of all moves among the elderly fall into the two main categories of moving in the Litwak and Longino framework (namely amenity and support moves). This emphasizes the need to embrace a more general framework in discussing elderly migration.

DeJong's study also suggests that support movers are differentiated along other dimensions; they are in poorer health, and are particularly likely to have experienced recent deterioration in health; being female and living alone are also associated with higher propensities to be support movers. Although we do not 
Table 4.

Classification of Elderly Mobility Types from the Survey on Aging and Independence, Canada: 1991

\begin{tabular}{|c|c|}
\hline Classification & Reason for Move \\
\hline Support & $\begin{array}{l}\text { - to receive care/support from a relative } \\
\text { - decline in health of self or spouse } \\
\text { - to be close to family/friends } \\
\text { - to be close to services }\end{array}$ \\
\hline Amenity & $\begin{array}{l}\text { - wanted more opportunities for recreation, } \\
\text { leisure and physical activity } \\
\text { climate }\end{array}$ \\
\hline Housing & $\begin{array}{l}\text { - previous home too big or too small } \\
\text { - landlord/owner sold property } \\
\text { - upgrade accommodation } \\
\text { - bought/built a house } \\
\text { - wanted less work } \\
\text { (low maintenance, fewer stairs, etc.) } \\
\text { - sold house }\end{array}$ \\
\hline Retirement & - retirement of self or spouse \\
\hline Separated/Divorced/Widowed & $\begin{array}{l}\text { - separation or divorce } \\
\text { - death of spouse }\end{array}$ \\
\hline Financial & - financial reasons \\
\hline Employment & $\begin{array}{l}\text { - to be close to work/school } \\
\text { - job change or transfer }\end{array}$ \\
\hline Other & $\begin{array}{l}\text { - to provide care/support to a relative } \\
\text { - house burnt/demolished } \\
\text { - needed a change } \\
\text { - marriage } \\
\text { - other reason }\end{array}$ \\
\hline
\end{tabular}

Source: Survey on Aging and Independence, 1991. 
Table 5.

Reasons Cited for Elderly Mobility by Age, Canada: 1991

\begin{tabular}{|c|c|c|c|c|c|}
\hline $\begin{array}{l}\text { Reasons } \\
\text { for } \\
\text { Moving } \\
\end{array}$ & $55-59$ & $60-64$ & $65-69$ & $70-74$ & $75+$ \\
\hline Support & $8.7 \%^{1}$ & $11.9 \%$ & $18.6 \%$ & $19.7 \%$ & $28.2 \%$ \\
\hline Amenity & $9.8 \%$ & $5.8 \%$ & $7.0 \%$ & $15.6 \%$ & $8.8 \%$ \\
\hline Housing & $33.5 \%$ & $24.9 \%$ & $28.9 \%$ & $25.8 \%$ & $27.1 \%$ \\
\hline Retirement & $7.0 \%$ & $16.3 \%$ & $17.6 \%$ & $10.8 \%$ & $5.9 \%$ \\
\hline Separated/ & & & & & \\
\hline Divorced & $7.2 \%$ & $6.6 \%$ & $5.9 \%$ & $6.9 \%$ & $8.7 \%$ \\
\hline Financial & $10.4 \%$ & $8.9 \%$ & $10.7 \%$ & $7.6 \%$ & $6.9 \%$ \\
\hline Employment & $7.0 \%$ & $10.0 \%$ & $1.2 \%$ & $0.3 \%$ & $1.0 \%$ \\
\hline Other & $16.4 \%$ & $15.6 \%$ & $10.0 \%$ & $13.3 \%$ & $13.5 \%$ \\
\hline Total & $100.0 \%$ & $100.0 \%$ & $100.0 \%$ & $100.0 \%$ & $100.0 \%$ \\
\hline $\begin{array}{l}\text { Percent of } \\
\text { Movers in last } \\
5 \text { years who } \\
\text { cite a support } \\
\text { reason for } \\
\text { having moved }\end{array}$ & $10.5 \%^{2}$ & $14.5 \%$ & $23.6 \%$ & $25.1 \%$ & $35.7 \%$ \\
\hline
\end{tabular}

Source: 1991 Survey on Aging and Independence

${ }^{1}$ Among movers in the last 5 years aged 55-59, the proportion of all reasons given which are classed as 'support reasons' individuals can give multiple responses, so percent related to the total number of reasons cited rather than individuals.

${ }^{2}$ The proportion of movers who cite support reason as at least one of the reasons for having moved.

have the prospective data available in LSOA, the post move relationships are still revealing in the Canadian data. In Table 6A, it is clear that support movers are substantially more likely to be activity limited than either non-movers or all other movers; the corollary is that, in numeric terms, there are far more activity limited individuals who are non-movers than who are support movers, clearly raising the question of how many of these non-movers would like to move but are unable to do so. Table 6B looks at the differentiation among movers on the basis of marital status. In 11 of the 12 cells in Table $6 \mathrm{~B}$, those who are activity limited are at least 60 percent more likely to be support movers and, in half the 
Table 6.

\section{Activity Limitation and Support Moves} by Age, Sex, Canada: 1991

\begin{tabular}{|c|c|c|c|c|}
\hline \multicolumn{4}{|c|}{ A. Percent Activity Limited, by Mobility Status } & \\
\hline & \multicolumn{3}{|c|}{ Age Group } & \\
\hline & $55-64$ & 65-74 & $75+$ & \\
\hline & & Males & & \\
\hline No Move & $24.3 \%$ & $27.6 \%$ & $31.9 \%$ & \\
\hline Moved for 'Other' Reasons & $21.7 \%$ & $25.2 \%$ & $34.2 \%$ & \\
\hline \multirow[t]{2}{*}{ Moved for Support Reasons } & $40.1 \%$ & $55.6 \%$ & $46.5 \%$ & \\
\hline & & Females & & \\
\hline No Move & $22.8 \%$ & $31.8 \%$ & $41.5 \%$ & \\
\hline Moved for 'Other' Reasons & $27.0 \%$ & $28.8 \%$ & $28.6 \%$ & \\
\hline Moved for Support Reasons & $47.7 \%$ & $63.0 \%$ & $53.9 \%$ & \\
\hline \multicolumn{5}{|c|}{ B. Movers: Percent Who Moved for Support Reasons } \\
\hline & \multicolumn{2}{|c|}{ Married } & \multicolumn{2}{|c|}{ Not Married } \\
\hline & Male & Female & Male & Female \\
\hline \multicolumn{5}{|l|}{ 1. All Respondents } \\
\hline Respondents aged 55-64 & $13.3 \%$ & $8.9 \%$ & $9.4 \%$ & $16.9 \%$ \\
\hline Respondents aged 65-74 & $15.9 \%$ & $34.5 \%$ & $18.9 \%$ & $26.0 \%$ \\
\hline Respondents aged 75+ & $27.4 \%$ & $38.2 \%$ & $33.7 \%$ & $39.0 \%$ \\
\hline
\end{tabular}

2. By Activity Limitation

Respondents aged 55-64

Respondents aged 65-74

Respondents aged $75+$

Not Activity Limited

\begin{tabular}{lccc}
\hline $10.3 \%$ & $7.6 \%$ & $7.6 \%$ & $11.5 \%$ \\
$11.9 \%$ & $23.9 \%$ & $8.1 \%$ & $12.9 \%$ \\
$21.0 \%$ & $30.9 \%$ & $33.7 \%$ & $28.5 \%$ \\
\hline
\end{tabular}

Respondents aged 55-64

Activity Limited

Respondents aged 65-74

$23.9 \%$

$12.3 \%$

$13.0 \%$

$29.1 \%$

Respondents aged 75+

$24.6 \%$

$52.6 \%$

$47.2 \%$

$45.1 \%$

$38.6 \%$

$54.9 \%$

$32.3 \%$

$54.4 \%$

Relative Risk of Moving

Activity Limited/Not Activity Limited

Respondents aged 55-64

Respondents aged 65-74

\begin{tabular}{llll}
2.31 & 1.62 & 1.70 & 2.54 \\
2.06 & 2.20 & 5.83 & 3.50 \\
1.84 & 1.78 & 0.96 & 1.91 \\
\hline
\end{tabular}

Respondents aged $75+$

Source: Survey of Aging and Independence (1991) 
cells, the odds ratios are over 2 . The odds ratios are highest among non-married individuals aged 65-74. The decline for those over 75 reflects the fact that the rates of activity limitation for all individuals increases markedly after the age of 75 (Moore, Rosenberg and McGuinness, 1997) and a high proportion of people who move for any reason are likely to be activity limited in some degree.

An interesting aspect of the responses in Table $6 \mathrm{~B}$ is that married women over 65 are consistently more likely to say they moved for support reasons than married men. Since we presume that women and men are selected randomly as respondents from married couples, the implication is that a woman is more likely to identify a given circumstance as a support move than a man; this most probably reflects an imbalance in the perceived flow of 'help' between husband and wife. When a woman provides most of the support services for a man (meal preparation, housework, shopping, even personal care), the male often reports that he needs no help (see also Moore, Rosenberg and McGuinness, 1997); when the woman finds it difficult to cope and needs assistance, this need may not be perceived by the man.

Table 7.

Proximity of Family Member and Friend Respondent feels Closest to, Elderly 75 Years of Age and Over, Canada: 1991

\begin{tabular}{|c|c|c|c|}
\hline Proximity & Non-Movers & $\begin{array}{l}\text { 'Other' } \\
\text { Movers }\end{array}$ & $\begin{array}{l}\text { Support } \\
\text { Movers }\end{array}$ \\
\hline & \multicolumn{3}{|c|}{$\begin{array}{l}\text { Activity Limited, Non-Married Elderly } \\
\text { Proximity of Family Member Respondent Feels Closest to: }\end{array}$} \\
\hline Same Household & $21.4 \%$ & $22.7 \%$ & $35.4 \%$ \\
\hline Within Neighbourhood & $18.6 \%$ & $17.1 \%$ & $16.6 \%$ \\
\hline Within City or Town & $30.5 \%$ & $30.4 \%$ & $29.9 \%$ \\
\hline \multirow[t]{2}{*}{ Another City or Town } & $29.5 \%$ & $29.8 \%$ & $18.1 \%$ \\
\hline & \multicolumn{3}{|c|}{$\begin{array}{l}\text { Activity Limited, Elderly } \\
\text { Proximity of Friend Respondent Feels Closest to: }\end{array}$} \\
\hline Same Household & $3.8 \%$ & $0.4 \%$ & $6.4 \%$ \\
\hline Within Neighbourhood & $45.3 \%$ & $44.7 \%$ & $26.3 \%$ \\
\hline Within City or Town & $42.1 \%$ & $41.3 \%$ & $40.6 \%$ \\
\hline Another City or Town & $8.8 \%$ & $13.6 \%$ & $26.7 \%$ \\
\hline
\end{tabular}

Source: Survey of Aging and Independence (1991) 
Table 8.

\section{Logistic Regression Variables derived from the Survey on Aging and Independence,1991}

\section{Dependent Variables}

1. Use of formal support

2. Satisfaction with life as a whole $1=\quad$ Respondent received help from formal sources

$0=$ Respondent received support but not from formal sources

$1=\quad$ Respondent is very satisfied with life as a whole

$0=\quad$ Respondent is not very satisfied with life as a whole

\section{Inependent Variables}

\section{Sociodemographic Variables:}

1. Age

2. Age, squared

3. Female

4. Dissatisfaction with income
Single years of age from 55 to 80

Respondent's age squared

$1=\quad$ Respondent is female; 0 otherwise

$1=\quad$ Respondent's income and investments currently satisfy needs not very well or totally inadequately

$0=\quad$ Respondent's income and investments currently satisfy very well or adequately

5. Lives alone

6. Tenure status $1=\quad$ Respondent lives alone; 0 otherwise

$1=\quad$ Rented dwelling

$0=\quad$ Owned dwelling

Marital Status: reference category $=$ respondent is married

7. Single

8. Widowed/divorce/separated

\section{Health Variables:}

9. Activity Limited

10. Poor Health

\section{Support Variables}

11. Number of close friends

12. Number of close family members

13. Proximity of closest friend

14. Proximity of closest family member

15. Satisfaction - contact with friends

16. Satisfaction- contact with family members $1=\quad$ Respondent is single (never-married); 0 otherwise

$1=$ Respondent is widowed, divorce, or separated; 0 otherwise

$1=\quad$ Respondent activity limted; 0 otherwise

$1=\quad$ Respondent describes health as Fair or Poor

$0=\quad$ Respondent describes health as Good or Excellent

\section{Number of friends respondent feels close to}

Number of family members respondent feels close to

$1=\quad$ closest friend lives with same household or neighbourhood; 0 otherwise

$1=\quad$ closest family member lives with same household or neighbourhood; 0 otherwise

$1=\quad$ Respondent very satisfied with kind and frequency of contact with friends; 0 otherwise

$1=\quad$ Respondent very satisfied with kind and frequency of contact with family members; 0 otherwise

Size-of-place indicator: reference category $=$ urban area with population 500,000 or over

17. Other' urban

18. Rural

$1=\quad$ Respondent livers in an 'other' urban area; 0 otherwise

$1=$ Respondent lives in a rural area; 0 otherwise

Mobility Variable: reference category = respondent did not change residence in the previous 5 years

19. Other' mover

20. Support mover $1=\quad$ Respondent moved in the previous five years, but did not move for support reasons; 0 otherwise

$1=$ Respondent moved for support reasons in the previous five years; 0 otherwise 
It is expected that those who move for support reasons change their spatial relationship to family and friends. On a prospective basis, DeJong indicates that those individuals whose children live more than one hour away are almost twice as likely to be support movers, while Silverstein (1995) shows that declining health stimulates moves to be closer to children. In the SAI, we only have data on proximity after the move, but this is itself informative (Table 7).

Focusing specifically on the older, non-married elderly, there are clear differences between non-movers, support movers and other movers. Support movers are more likely to have their closest family member in the same household and much less likely to have them in another city. However, support movers are less likely to have their closest friend in the same neighbourhood and it is more likely for that person to be in another town or city. The inference is that the move for support reasons has the tendency not only to relocate closer to family who are more likely to be the source of personal care (Rosenthal and Gladstone, 1994), but also to move further away from the social network of friends which may have significant negative impacts on the everyday life of the individual. Overall, if we look at the expressed life satisfaction of elderly individuals, controlling for their movement experience as well as for socio-economic and health characteristics (Table 9) ${ }^{1}$, those who are support movers are significantly less likely to be very satisfied with life, even after controlling for poor health. Rowland (1996) suggests this decline in satisfaction is also strongly linked to a perceived loss of autonomy resulting from a move to increased dependency on others.

There are broader consequences of individuals making support moves. If elderly in declining health are moving to gain greater access to support from family, their use of formal services might be expected to be less than others. Table 10 provides an analysis of the likelihood of using formal support. As expected the proximity of family members reduces the use of formal supports, while it is substantially increased for those who live alone. It is clear that those who live in difficult financial circumstances have drastically lower access to formal support, a situation which is of major concern from a policy perspective. The additional impact of being a support mover on the likelihood of using formal supports is marginal. The rate of utilization is not significantly lower than for non-movers, but the sign is in the right direction; however, the difference between support movers and all other movers is significant and substantial, with other movers being much more likely to use formal services.

From a policy perspective, the geographical consequences of increases in support moves at older ages are of interest. We know from earlier studies that both the rate of population aging and the role of migration in that process is highly differentiated geographically and strongly linked to patterns of economic disadvantage within the country. We see differential rates of aging at both the regional and local levels. In particular, higher rates of aging are experienced in the Atlantic Provinces and the Prairies as well as in smaller urban centres across the country, particularly those where economic growth is slow. Do we see a linkage between the patterns of destinations for support movers and the overall structure of aging? Unfortunately, the geographical detail available in SAI is 
Table 9.

Satisfaction with Life, Activity Limited, 55 Years of Age and Older, Canada: 1991

Dependent Variable $=$ Satisfaction with Life as a Whole (coded as $1=$ Very Satisfied)

\begin{tabular}{|c|c|c|c|}
\hline $\begin{array}{c}\text { Independent } \\
\text { Variables } \\
\end{array}$ & $\begin{array}{c}\text { Parameter } \\
\text { Estimate }\end{array}$ & $\begin{array}{c}\text { Significance } \\
\text { Level }\end{array}$ & $\begin{array}{l}\text { Odds } \\
\text { Ratio } \\
\end{array}$ \\
\hline Intercept & -1.846 & & \\
\hline Age & .036 & & 1.037 \\
\hline Age, squared & -.000 & & 1.000 \\
\hline Female & .266 & $* * *$ & 1.305 \\
\hline Dissatisfaction with income & -1.265 & $* * *$ & .282 \\
\hline Lives alone & -.337 & $* * *$ & .714 \\
\hline Tenure status & & & \\
\hline $\begin{array}{l}\text { Single } \\
\text { Widowed/divorced/separated }\end{array}$ & -.345 & $* *$ & .709 \\
\hline $\begin{array}{l}\text { Number of close friends } \\
\text { Number of close family }\end{array}$ & .029 & $* * *$ & 1.029 \\
\hline $\begin{array}{l}\text { members } \\
\text { Proximity of closest friend } \\
\text { Proximity of closest family } \\
\text { member }\end{array}$ & .045 & $* * *$ & 1.046 \\
\hline Poor health & -.513 & $* * *$ & .599 \\
\hline 'Other' urban & .286 & $* * *$ & 1.331 \\
\hline Rural & .219 & $* *$ & 1.244 \\
\hline Support mover & -.245 & $* *$ & .783 \\
\hline 'Other' mover & .060 & & 1.062 \\
\hline
\end{tabular}

Age, age squared, support mover and other mover were forced into the model. Among the other variables only those whose coefficients were significant at the .01 level were entered.

$* * *=p>.01$
$* * \quad=p>.05$
$* \quad=p>.10$

Source: Survey of Aging and Independence (1991) 
Table 10.

Use of Formal Support Services, Activity Limited, 55 Years of Age and Older, Canada: 1991

Dependent Variable $=$ Use of Formal Support (coded as 1 = Very Satisfied)

\begin{tabular}{|c|c|c|c|}
\hline $\begin{array}{c}\text { Independent } \\
\text { Variables } \\
\end{array}$ & $\begin{array}{c}\text { Parameter } \\
\text { Estimate } \\
\end{array}$ & $\begin{array}{c}\begin{array}{c}\text { Significance } \\
\text { Level }\end{array} \\
\end{array}$ & $\begin{array}{l}\text { Odds } \\
\text { Ratio } \\
\end{array}$ \\
\hline Intercept & -10.676 & $* * *$ & \\
\hline Age & .119 & & 1.221 \\
\hline $\begin{array}{l}\text { Age, squared } \\
\text { Female }\end{array}$ & -.001 & & .999 \\
\hline Dissatisfaction with income & -.680 & $* * *$ & .507 \\
\hline Lives alone & .400 & ** & 1.491 \\
\hline \multicolumn{4}{|l|}{ Tenure status } \\
\hline \multicolumn{4}{|l|}{ Single } \\
\hline \multicolumn{4}{|l|}{ Widowed/divorced/separated } \\
\hline \multicolumn{4}{|l|}{ Number of close friends } \\
\hline $\begin{array}{l}\text { Number of close family } \\
\text { members }\end{array}$ & -.074 & ** & .929 \\
\hline \multicolumn{4}{|l|}{$\begin{array}{l}\text { Proximity of closest family } \\
\text { member }\end{array}$} \\
\hline \multicolumn{4}{|l|}{ Poor health } \\
\hline \multicolumn{4}{|l|}{ 'Other' urban } \\
\hline \multicolumn{4}{|l|}{ Rural } \\
\hline Support mover & -.196 & & .822 \\
\hline 'Other' mover & .331 & & 1.392 \\
\hline
\end{tabular}

Age, age squared, support mover and other mover were forced into the model. Among the other variables only those whose coefficients were significant at the .01 level were entered.

$$
\begin{aligned}
& * * *=\mathrm{p}>.01 \\
& * * \quad=\mathrm{p}>.05 \\
& * \quad=\mathrm{p}>.10
\end{aligned}
$$

Source: Survey of Aging and Independence (1991) 
Table 11.

Distribution of Support Moves by Region, Size-of-Place and Age, Canada: 1991

\begin{tabular}{llll}
\hline Regions and & & \multicolumn{3}{c}{ Age Group } \\
Size-0f-Place & $55-64$ & $65-74$ & $75+$ \\
\cline { 2 - 4 }
\end{tabular}

A. Percent Activity Limited, by Mobility Status

Canada

Regions of Canada
$2.8 \%$

$5.0 \%$

$6.3 \%$

Atlantic Provinces

Quebec

Ontario

Prairie Provinces

British Columbia

Size-of-Place

500,000 or more

100,000 to 499,999

30,000 to 99,999

15,000 to 29,999

Small Urban Areas

Rural Areas

$2.9 \%$

$3.5 \%$

$2.4 \%$

$2.8 \%$

$2.0 \%$

$2.7 \%$

$2.5 \%$

$2.2 \%$

$2.2 \%$

$4.2 \%$

$2.6 \%$
B. Percent of Movers Who are Support Movers

Canada

$12.5 \%$

$24.2 \%$

$35.7 \%$

Regions of Canada

Atlantic Provinces

$18.6 \%$

Quebec

Ontario

Prairie Provinces

British Columbia

Size-of-Place

$\mathbf{5 0 0 , 0 0 0}$ or more
$\mathbf{1 0 0 , 0 0 0}$ to 499,999
$\mathbf{3 0 , 0 0 0}$ to 99,999
$\mathbf{1 5 , 0 0 0}$ to 29,999
Small Urban Areas
Rural Areas

100,000 to 499,999

30,000 to 99,999

Small Urban Areas

Rural Areas
$16.1 \%$

$10.2 \%$

$15.3 \%$

$7.3 \%$

$12.4 \%$

$11.5 \%$

$8.8 \%$

$10.9 \%$

$16.3 \%$

$13.7 \%$
$3.9 \%$

$5.5 \%$

$5.1 \%$

$5.8 \%$

$5.7 \%$

$6.3 \%$

$9.6 \%$

$8.1 \% \quad 9.6 \%$

$5.8 \%$

$6.3 \%$

$8.5 \%$

$8.4 \%$

$8.1 \%$

$4.7 \%$
$2.9 \%$

$26.4 \%$

$42.7 \%$

$24.1 \%$

$29.2 \%$

$20.7 \%$

$34.0 \%$

$27.3 \%$

$42.5 \%$

$28.1 \%$

$40.2 \%$

Source: Survey of Aging and Independence (1991) 
limited but we can identify some intriguing patterns (Table 11). While British Columbia is the locus of the highest proportions of individuals who are movers and of individuals who are support movers, the relative concentration of support movers focuses on the Prairies and Atlantic Provinces, with Ontario exhibiting significantly lower proportions in each age group than the rest of Canada. Those regions which are accumulating elderly and tend to be disadvantagedeconomically receive more than their share of support movers. Newbold (1993) has also identified the issue of return migration, or the migration back to the province of birth, as being strongly focused on these regions. When we consider sizes of urban places, there is a tendency for smaller urban places to receive

higher proportions of support movers; again these tend to be the locus of slow growth communities with relatively high proportions of elderly.

\section{Discussion}

For a long time, mobility among the elderly received little academic attention as they were regarded collectively as a group who moved relatively infrequently compared with other segments of the population. However, as the size and political presence of the elderly has grown, both absolutely and relatively, both the complexity and the importance of relocation among the elderly has been appreciated. Not only are the elderly exposed to a different mix of life events which trigger mobility but the consequences of their moves both for the welfare of individuals and with regard to the geography of demand for health care and social services are of real policy concern.

Recent conceptual discussions of elderly mobility have stressed the role played by specific life events in triggering move responses (Litwak and Longino, 1987; Northcott, 1988; DeJong et al., 1995). Retirement is seen to generate an increase in moves to high amenity locations, while declines in health at later dates are particularly important in stimulating moves to be close to family and the receipt of support for activities of daily living. As DeJong et al. (1995) argue, these events, which are particularly relevant to the elderly, can be embedded in a more general framework which expresses movement as an outcome of the relation between values, expectations and experience.

In this paper we have focussed specifically on the role of support moves in the elderly movement experience. The results are certainly suggestive, although the lack of a longitudinal framework makes it difficult to produce more definitive statements. The increasing prevalence of support moves with increasing age is certainly consistent with the Litwak and Longino developmental model, while it is also clear that the health status of support movers is significantly poorer than either the non-moving population or the set of individuals who move for other reasons. Yet we must also recognize that the majority of those whose health is poor do not move and the majority of those who move within the residential community, even at older ages, do not do so for reasons related to declining health or access to greater support. Other life events, financial difficulties, adjustments to changing housing needs and moves to better environments, 
whether physical or social, still provide stimuli to move even for the older elderly (those over 75). We also do not have access to data on moves by those in poorest health from the residential community to institutions. Such moves would undoubtedly raise the movement rates, particularly of those over 75 , but we must have access to other data sources such as NPHS which include both residential and institutional populations in order to assess the magnitude of these effects.

Within a general framework which regards mobility as an adjustment to changing circumstances for individuals, the focus on support moves begs the question of what happens to those experiencing declining health who would like to move to gain greater support but do not have the opportunity to do so. The concept of 'blocked moves' has been around for some time (Michelson, 1977), but it perhaps deserves more attention, since the social consequences of being unable to make such adjustments could well be severe. If individuals both experience declines in health and have nobody to turn to for additional help, they are both more likely to be dependent on formal support services and, when further deterioration in health occurs, become prime candidates for institutionalization. NPHS has the potential to address these questions as additional waves are added to the first survey and thereby add greatly to our understanding of the dynamics of aging and social support.

The nature of support moves and the general relation between health status and use of formal supports has potentially important geographical implications. We know from previous research (Moore, Rosenberg and McGuinness, 1997) that individuals, particularly older females, who live in large urban areas are more likely to live alone and that such individuals also have a high propensity to fall below the low-income cut-off line developed by Statistics Canada as a measure of economic disadvantage. One inference from the findings in this paper are that support movers tend to accumulate in small urban centres and also in those regions where economic growth is slower; the other side of the coin is that urban areas may also be the locus not only of older individuals with fewer supports but that there may also be significantly more blocked moves. If this were to be the case, then this poses a significant challenge for social and health care agencies in the larger urban areas. There is a need for more detailed research on geographic differences in the structure of support networks and the extent to which they contribute to geographic differences in the adjustments of elderly to changes in health.

As one considers the mobility behaviour of the elderly, the role of the third stage of the Litwak and Longino framework, the transition to institutional living, becomes critical. Little research has been undertaken on the population dynamics of transitions between communities and institutions and back. Although we have no data as yet on transitions in Canada, we can provide lower bounds on these shifts from assessment of changes in the age distribution of individuals in institutions. These numbers are large in the current context, with the lower bound reaching $10.4 \%$ of the female population over 80 and $5.4 \%$ of the male population moving to institutions between 1986 and 1991 (Moore, Rosenberg and McGuinness, 1997). With numbers this large, significant 
geographical effects also follow. The distribution of rates of institutionalization is highly variable, reflecting both individuals at risk and differences in provincial and local policies regarding access to institutions. Manitoba, for example has significantly lower rates, reflecting in part its long term commitment to home care. The bottom line, however, is that we know very little about the relation between the geographical distributions of supply and demand in regard to institutional care.

Two issues arise from the discussion of institutionalization in the context of studies of elderly mobility. The first concerns the factors which identify the risk of transition to institutional living and the role played by support moves in deferring these transitions. Does the inability to make a support move increase the risk of institutionalization or does it increase the length of time that an individual spends in straightened circumstances prior to moving to an institution. Secondly, the structure of elderly migration is selective not only with respect to who moves but also to where they move. The tendency for support movers to focus more on small urban centres and low growth regions also implies that the elderly in-migrant streams in these areas contain a higher proportion of individuals in poor health. To what extent is this reflected first in the demand for health care and social services in these areas and, secondly, how does it effect the demand for institutionalization? It is these issues which arise as a consequence of the selective character of elderly migration which need additional attention in the future, with particular emphasis on the use of longitudinal files.

\section{Acknowledgements:}

The research reported in this paper was supported by funding from the Statistics Canada under its Census Analysis Monograph Program and by the Social Sciences and Humanities Research Council of Canada. Their support is gratefully acknowledged.

\section{Endnote:}

1. Table 8 contains the definitions of the variables used in Tables 9 and 10.

\section{References:}

DeJong, G. F. and J. T. Fawcett. 1981. "Multidisciplinary frameworks and models of migration decision-making," in G. F. DeJong and R. W. Gardner (eds.), Migration Decision Making. New York: Pergamon.

DeJong, G. F., J. M. Wilmoth, J. L. Angel, and G. T. Cornwell. 1995. "Motives and the geographic mobility of very old Americans," Journal of Gerontology 50B, 6: S395-S404. 
Gibson, D. M. and D. T. Rowland. 1984. "Community vs. institutional care: the case of the Australian aged," Social Science and Medicine 18(11): 997-1004.

Golant, S. 1992. "The suburbanization of the U.S. Elderly," in A. Rogers, (ed.) Elderly Migration and Population Redistribution. London: Belhaven Press, pp.163-180.

Litwak, E. and C. F. Longino. 1987. "Migration patterns among the elderly: a developmental perspective," The Gerontologist 27: 266-272.

Meyer, J. W. and A. Speare. 1985. "Distinctive elderly mobility: types and determinants," Economic Geography 61: 79-88.

Michelson, W. 1977. Environmental Choice, Human Behoviour and Residential Satisfaction. New York: Oxford.

Moore, E.G. and W.A.V. Clark. 1987. "Stable structure and local variation: a comparison of household flows in four metropolitan areas," Urban Studies 23: 185-96.

Moore, E. G. and M. W. Rosenberg. 1993. "Migration, mobility and population redistribution," in L. S. Bourne and D. Ley (eds.), The Changing Social Geography of Canadian Cities. Montreal: McGillQueen's Press.

Moore, E.G., M. W. Rosenberg and D. L. McGuinness . 1997. Growing Old in Canada: Demographic and Geographic Perspectives. Toronto: Nelson and Statistics Canada

Moore, E.G. and D. L. McGuinness. 1997. Geographical dimensions of aging: the Canadian experience, 1986-1991. Paper presented at the Conference on Migration and Restructuring, University of Georgia.

Mutchler, J. E. and J. A. Burr. 1991. "A longitudinal analysis of household and nonhousehold living arrangements in later life," Demography 28: $375-390$.

Newbold, B. 1993. Characterization and explanation of primary, return and onward interprovincial migration: Canada 1976-1986, unpublished Ph.D. thesis, Department of Geography, McMaster University.

Northcott, H. C. 1988. Changing Residence: The Geographic Mobility of Elderly Canadians. Toronto: Butterworths, xxi $+135 \mathrm{pp}$.

OECD. 1996. "Caring for frail elderly people: policies in evolution," Social Policy Studies No. 19. Paris: Organization for Economic Cooperation and Development. 
Ram, B. 1990. New Trends in the Family: Demographic Facts and Features. Ottawa: Statistics Canada, cat. 91-535.

Rogers, A. 1988. "Age patterns of elderly migration: an international comparison," Demography 25(3): 355-370.

Rosenberg, M. W. and E. G. Moore. 1990. "The elderly, economic dependency, and local government revenues," Environment and Planning. C, Government and Policy 8: 149-165.

Rosenthal, C. and J. Gladstone. 1994. "Family relationships and support in later life," in V. Marshall and B. McPherson, (eds.) Aging Canadian Perspectives. Peterborough, Ontario: Broadview Press. pp. 158-174.

Rowland, D. T . 1996. "Migration of the aged," in P. W. Newton and M. Bell (eds.) Population shift: mobility and change in Australia, Canberra, Australian Government Publishing Service.

Silverstein, M. 1995. "Stability and change in temporal distance between the elderly and their children," Demography 32(1): 29-44.

Speare, A., R. Avery and L. Lawton. 1991. "Disability, residential mobility, and changes in living arrangements," Journal of Gerontology: Social Sciences 46: S133-S142.

Speare, A. and J. W. Meyer. 1988. "Types of elderly residential mobility and their determinants," Journal of Gerontology: Social Sciences 43: S74-S81.

Wiseman, R.F., and C. Roseman. 1979. "A typology of elderly migration based on the decision- making process," Economic Geography 55: 324-337.

Wiseman, R.F. 1980. "Why older people move: theoretical issues," Research on Aging 2: 141-154.

Received January 1997; Revised April 1998 
